\title{
PORT COMPETITION THROUGH HINTERLAND ACCESSIBILITY: THE CASE OF SPAIN
}

\begin{abstract}
While immediate port hinterlands remain relatively captive, distant hinterlands are fiercely contested. Where road is the dominant mode, transport costs are a function of distance which is therefore often the key determinant of port choice. Where distance is sufficiently long to enable rail to compete, other factors become important, such as terminal availability and frequency of rail services. Many ports are increasing the use of rail transport to ease port congestion, reduce transport costs or decrease environmental externalities. The question this paper poses is to what extent has the development of inland terminals and container rail shuttles influenced the ability of Spanish ports to compete for distant hinterlands?

The paper analyses competition between three major container ports in Spain: Barcelona, Bilbao and Valencia. The methodology was based on using GIS to produce a set of maps which identify relationships between the location of the main logistics platforms, the configuration of the terrestrial transport infrastructure and the provincial origin/destination of the maritime container traffic and its inter-port distribution from 2008 to 2013. We use longitudinal data on port shipments from inland regions to investigate the changing spatial distribution of port hinterlands and then we map these changes against road and rail traffic flows, in order to explore if a correlation exists between the market share of ports in contestable hinterlands and the use of rail shuttles to key inland terminals. We find that while some inland terminals have been successful in consolidating traffic on rail services, ports (e.g. Valencia) have been able to capture distant hinterlands even with a low usage of rail. This suggests that the use of rail is not the key driver behind successful capture of distant markets, but rather distance remains the primary determinant of port choice. In future, the port of Valencia should seek to grow its volumes in areas where its traffic is currently less concentrated, around rail terminals.
\end{abstract}

Keywords: container port, rail, corridor, intermodal terminal, logistics platform. 


\section{Introduction}

In recent years there has been much focus on hinterland transport and intermodal corridors as tools of port competition. Yet, inland distances from the port to origins and destinations remain a key variable in port choice, regardless of improvements in hinterland transport. Ports continue to dominate their captive contiguous hinterlands while competing with other ports for distant hinterlands, wherever distance tends to become less important over a certain threshold. At that point, the quality of intermodal services, links and infrastructure are key. Therefore, questions remain regarding the use of intermodal corridors and the role of terminals and logistics platforms in consolidating this traffic, so as to overcome the role of distance as the traditionally key variable.

For empirical application, this paper focuses on three Spanish ports: Barcelona, Bilbao and Valencia, which compete for the inland regions of the country, in particular the zones of Madrid and Zaragoza. The paper builds on previous work, looking at the changing composition of the Spanish hinterland, as a result of port choice (Garcia-Alonso et al, 2016), and at the development of inland terminals by Spanish ports (Monios, 2011), by examining the role of terminals and rail corridors in port competition for distant hinterlands. The research question of the paper is thus the extent to which the development of inland terminals and container rail shuttles has influenced the ability of Spanish ports to compete for distant hinterlands. The methodology was based on using GIS to produce a set of maps which identify relationships between the location of the main logistics platforms, the configuration of the terrestrial transport infrastructure and the provincial origin/destination of the maritime container traffic and its inter-port distribution from 2008 to 2013. The aim is to explore if a correlation exists between the market share of ports in contestable hinterlands and the use of rail shuttles to key inland terminals.

\section{Literature review}

\section{The role of the hinterland in port competition}

The last decade has witnessed a growth in research exploring the role of intermodal transport, inland terminals and hinterland access in port competition (Wilmsmeier et al, 2011; Rodrigue et $a l, 2010)$. Major drivers for such developments include vertical integration in the supply chain (Van de Voorde and Vanelslander, 2009; Notteboom, 2008; Olivier and Slack, 2006) and the need to address the high proportion of inland transport costs (Graham, 1998; Notteboom and Winkelmans, 2001; Notteboom and Rodrigue, 2005). As a result, the quality of hinterland transport links has become one of the key aspects of port choice albeit not the most dominant (Bichou and Gray, 2004; Song and Yeo, 2004; Parola and Sciomachen, 2009; Ferrari et al, 2011; Nazemzadeh \& Vanelslander, 2015). 
Using inland terminals as tools of competition in contestable hinterlands is not new (van Klink and van den Berg, 1998) but it has been studied more closely in recent years (Monios and Wilmsmeier, 2013), as some ports have become more proactive in extending or even maintaining their hinterlands (McCalla, 1999; Notteboom and Rodrigue, 2005; Monios and Wilmsmeier, 2012). Yet, despite evidence of a significant number of cases where ports have been proactive, it remains the case that immediate hinterlands remain the primary focus of most ports (Notteboom, 2010; Guerrero, 2014). While there has been significant investment in inland terminals for reasons of port competition, many developments are also intended to boost economic development as well as reduce emissions through modal shift, thus many terminals are developed by consortia involving both port and inland actors (Notteboom and Rodrigue, 2005; Bergqvist et al, 2010; Rodrigue et al, 2010; Monios and Wilmsmeier, 2012). In many of these cases (certainly in Spain - see next section), the distance was not great enough to give rail a clear advantage, therefore the investments were rather speculative and could not attract sufficient private funds. Many of the investments were therefore made (at least partially) by public sources, e.g. local and regional governments. This paper aims to determine if these new terminal developments in Spain have in fact led to an increase in the use of rail for port hinterland transport, which would suggest that the investments were justified, whereas if they are underutilised, it would suggest that such proactive public sector development may not be the correct strategy.

The literature identifies that, while intermodal access to port hinterlands is unquestionably important, there are a number of ways ports may engage in these activities, such as developing a terminal or a rail service directly or in partnership with rail operators. Yet, there is not a clear prediction of what will happen in each case, as factors remain contextual, especially in regions with short to medium inland distances, where rail faces fierce competition from road transport. In countries with long distances (e.g. inland areas of the United States - see Monios and Lambert, 2013) rail will often take the majority of modal share, subject to the availability of quality infrastructure and terminals. The latter may be lacking in other parts of the world with long distances (e.g. Africa - see UNCTAD, 2013), where road may still dominate. Large investments have been made in China to upgrade infrastructure, so as to provide capacity for container shuttles, and allied to this is the need for logistics facilities, to provide containerisation services inland, as well as customs clearance (Monios and Wang, 2013). In a country like Spain though, inland distances do not afford rail a natural advantage; to compete with road, rail must be able to operate regular well-loaded shuttles in order to achieve scale economies. To support this operation, a growth in logistics platforms has been observed, although this does not always translate into increased use of rail, due to industry inertia regarding modal shift.

\section{Applications to Spain}


Specifically with regard to Spain, it is already known that i) the port-province distance remains a key variable in port choice, when analysed from a landside perspective (Garcia-Alonso and Sanchez-Soriano, 2009); ii) the ranking of ports was quite stable, from a spatial perspective, during the analysed period (Garcia-Alonso and Sanchez-Soriano, 2010); iii) the impact of land transport costs is slightly higher than that of maritime transport costs in the port choice process (Veldman et al, 2011); and iv) the hinterland of Valencia port has experienced the best evolution over the last decade in comparison with the other main Spanish container ports (Martínez-Pardo and Garcia-Alonso, 2014; Garcia-Alonso et al, 2016).

Previous research reveals that the development of the hinterland of the main Spanish container ports during the last decade depended mainly on the traffic generated in nearby provinces. Garcia-Alonso et al (2016) found that Valencia grew its hinterland and decreased the spatial concentration of its traffic. One of the key questions raised in that research was whether it is more desirable for a port to extend its geographical scope, so as to reduce its geographical dependence, or instead to increase traffic concentration in order to facilitate growth of rail corridors. Additional factors listed by Garcia-Alonso et al (2016) as possible explanatory elements of the evolution of port hinterlands were port accessibility, the road and rail network available, and the existence of inland terminals and logistics platforms. Questions remain regarding the use of intermodal corridors, and the role of terminals and logistics platforms in consolidating traffic, so as to overcome the significance of distance as the, traditionally, key variable.

Some authors have analysed the role of inland terminals and intermodal corridors in Spanish port competition. Monios (2011) explored inland terminal development strategies by Spanish port authorities and terminals, particularly the Zaragoza Maritime Terminal (TMZ), Azuqueca de Henares and Coslada. Rodrigue et al. (2010) also considered the role of TMZ as an inland terminal for the port of Barcelona. Monios and Wilmsmeier (2012) examined the regionalization process of the major Spanish container ports: Algeciras, Barcelona, Bilbao and Valencia. Van den Berg and De Langen (2011) studied the success of the port of Barcelona in attracting container traffic from distant hinterlands, as well as paying attention to the role of the logistics platforms located in Zaragoza: Plaza and TMZ. More recently, Monios (2015) addressed again the main Spanish logistics facilities, while analysing the relationships between intermodal terminals and logistics platforms. The latter work raised the question whether co-locating a terminal next to a logistics platform could result in increased modal shift to rail.

\section{Methodology}


We link the inland distribution of maritime traffic with the location of the main logistic platforms and intermodal terminals, considering the spatial configuration of the main road and rail networks. We use a Geographic Information System (GIS) framework to produce a set of maps which demonstrate certain relationships among all relevant factors. In this first approach, the aim is to provide a picture whereby the location of the main logistics platforms and the configuration of the terrestrial transport infrastructure can be compared with the provincial origin of the maritime traffic and its inter-port distribution. Rather than to draw conclusions about the effective role of logistics platforms, the goal is to ascertain if there is any spatial pattern in the port choice process, from the provincial perspective, according to the terrestrial infrastructure endowment. The analysed period runs from 2008 to 2013 (i.e. from the beginning of the economic crisis to the last year of data availability, for all the data sources consulted).

The first step was to map the provincial traffic flows of each port. For this purpose, the database of the Spanish Customs Statistics and the directory of Spanish exporting-importing companies of the Chamber of Commerce were used. The former provides information about flows of foreign trade generated at each province, which can be linked to the Spanish port serving as gateway. The latter provides information about the location of firms generating those trade flows.

A drawback of the directory of Spanish exporting-importing companies is that it does not include information on the main mode of transport used by them. For that reason, only flows to American and Asian countries were used to assess the evolution of port traffic distribution. Besides, only containerized exports were considered, those generated within each of the 47 Spanish peninsular provinces. Due to lack of data from France and Portugal, traffic generated outside the Spanish borders was ignored. This latter fact does not affect our conclusions: the biggest volume of inland maritime traffic is generated within the Spanish borders and, secondly, we are only interested in the impact of the logistic platforms and rail corridors on the port choice for the national flows.

Once the spatial distribution of traffic has been generated and changes over time observed, these findings will be cross referenced with the provision of road and rail infrastructure and road and rail traffic between each province and port. Additionally, by mapping the locations of intermodal terminals and logistics platforms, relationships can be investigated between such locations and the changes over time for each province.

\section{Results}

\section{Overview of the Spanish port system}


Spain constitutes a suitable case study for the topic analysed in this paper because of the geographical extent of the country and the characteristics of the national transport infrastructure: i) the availability of a large number of port facilities, all located along a lengthy peninsular coast, gateways for the Atlantic or the Mediterranean; ii) the existence of logistics platforms and intermodal terminals linked to the main container ports which compete for the landside traffic and whose hinterlands consequently overlap; and iii) the radial design of the main road and rail networks. Furthermore, the Spanish port system, the inland maritime traffic distribution and the intermodal facilities existing in Spain have already been analysed in previous articles, raising questions to be addressed in this paper.

The four major container ports of Spain are Valencia, Algeciras, Barcelona and Bilbao. Due to its strategic location in the south, the port of Algeciras is a transhipment specialist, albeit with a small amount of hinterland flows, thus the analysis focuses on the other three ports. Situated on the north coast, Bilbao specialises in short-sea and feeder traffic from the northern range ports of Europe. Valencia and Barcelona on the east coast are the two major ports for Spanish deep sea cargo, although Valencia does more transhipment than Barcelona and indeed this is one of the reasons for its strong growth in recent years. Figures 1 shows the evolution of TEUs of the analysed ports and Figure 2 shows the rate of growth of their TEUs as well as total traffic over the period in question. The geography of Spain means that the major hinterland of each port is its local area, with insufficient distance for rail competition. The main inland markets of significance that are analysed here are the greater Madrid area (population 5-6 m) and Zaragoza in the region of Aragón north-eastern Spain, which is the major industrial region of the country.

\section{FIGURE 1}

FIGURE 2

\section{Mapping the changing hinterland}

Figure 3 maps the total distribution of Spanish port traffic in 2008 and 2013. The maps show the changes over time in traffic distribution/generation from a spatial perspective. They reveal some small changes in the composition of national trade, with the Valencia region decreasing from $39.5 \%$ to $36.8 \%$ and the Barcelona region increasing slightly from $17.7 \%$ to $18.7 \%$. Freight intensity around Bilbao has not changed significantly. The key contestable inland zones addressed in this paper have also changed, with the Madrid area increasing its share from 5.7\% to $7.9 \%$ and Zaragoza decreasing its importance, from a national perspective, from $3.8 \%$ to $2.4 \%$. Our next step was to map the changes in hinterlands, for each of the three ports under 
analysis, cross referenced with major infrastructure corridors, intermodal terminals and logistics platforms. These results are shown in Figure 4, Figure 5 and Figure 6.

\section{FIGURE 3}

FIGURE 4

FIGURE 5

FIGURE 6

Figure 4 shows that Barcelona's immediate hinterland has reduced its importance slightly from $57.8 \%$ to $54.1 \%$, while Madrid has increased its share from 3.8\% to 5.3\% and Zaragoza has declined from $9.9 \%$ to $4 \%$. The major change comes from the nearby province of Lleida, from $3.5 \%$ to $13.7 \%$, which is nonetheless within Barcelona's traditional hinterland. Figure 5 reveals little change in the share of Bilbao traffic contributed from its more distant hinterlands of Madrid and Barcelona and further afield, but its share from Zaragoza rose from virtually nothing to $3.7 \%$. There were also some changes in Bilbao's more immediate area, with its home province of Biscay increasing from $19.6 \%$ to $26.2 \%$. The port of Valencia demonstrated some interesting increases in its distant hinterland, with its home province reducing in importance from $73.8 \%$ to $67.1 \%$ as Madrid rose from $6 \%$ to $9.8 \%$; it even captured hinterland (from $2.6 \%$ to $4.1 \%$ ) from the area around Barcelona.

A number of interesting conclusions can be drawn from the above findings, further analyzed below. First, the major share of port traffic is still coming from the nearest provinces generating maritime traffic, i.e. the captive hinterlands. Looking further inland, the locations generating the biggest volume of container traffic are those located along the major road routes; the main logistics platforms are located along these routes, crossing the contestable hinterland. These findings support the hypothesis of Garcia-Alonso and Sanchez-Soriano (2009) that the hinterland distance is still an important variable for inland freight transport. This means that firms, when selecting their location, take into account the location of the ports, able to offer the services they need. Firms already established tend to choose the services offered by the nearest port. MartinezPardo and Garcia-Alonso (2014) and Garcia-Alonso et al (2016) went even further by suggesting that the evolution of port hinterlands can be influenced by the nearest port infrastructure and the corridors linked to its hinterland. From the location of the logistics platforms marked on Figures 4-6, it could be that such platforms contribute to reinforcing the terrestrial transport network. One interesting question to be taken further is whether such platforms serve only to expand 
contestable hinterlands or to promote the generation of new traffic by reducing generalized costs of transport. This is considered below.

\section{Key inland battlegrounds: Madrid and Zaragoza}

From a total traffic perspective, these two inland markets are not of essential importance to the ports, representing $9.3 \%, 15.3 \%$ and $11.9 \%$ of the total throughput of the ports of Barcelona, Bilbo and Valencia, respectively. However, these two inland markets are the most competitive hinterland locations as all three ports analysed in this paper can compete for them more realistically than they can compete for each other's local hinterland. Thus they provide a suitable location for analysis of Spanish port hinterland competition.

Figure 7 shows the share of port traffic for each of these two key inland regions. The figure reveals that, over the last decade, Valencia has drastically increased its share of Madrid traffic, up to over $50 \%$, while Bilbao has dropped from $26 \%$ to only $12 \%$. Barcelona suffered a marked decline from $22 \%$ to $16 \%$ in 2012 but has since recovered to $24 \%$. Flows from Zaragoza also show an interesting change during this time. Valencia increased its share at the expense of both Barcelona and Bilbao throughout the decade, but its 32\% in 2012 has dropped back to 27\%, while Barcelona's drop from $63 \%$ to $47 \%$ has recovered to $59 \%$. These results might suggest the continued importance of distance, as Valencia is closer to Madrid while Barcelona is closer to Zaragoza. However, these figures represent total traffic, rather than modal split; to understand the role of intermodal access to port hinterlands, rail traffic to terminals is discussed in the next section, and terminals themselves in the section following.

\section{FIGURE 7}

\section{Transport mode: road vs rail}

Figure 8 shows the evolution of the share of rail compared to road transport since 2008. While Bilbao has remained steady, Barcelona has grown significantly from less than $2 \%$ in 2008 to almost 8\% in 2013 and, after initial growth, Valencia has dropped slightly. Figures for intermodal terminals (see next section) do not show the spike for Valencia in 2010, which means that it was another form of rail traffic. Indeed, other ports such as Santander, Pontevedra, La Coruña and Gijón have rail shares above 10\%, but these are bulk and automobile traffic, for which rail is the natural mode. In the next sections we look in more detail at container shuttles, as that is where competition with road is fiercest. 


\section{FIGURE 8}

The apparently small increase of rail share in each port becomes more relevant when taking into account that national rail traffic fell by $15 \%$ in the same period. Besides, the amount of container traffic transported by rail -by the main operator (RENFE)- has remained constant, thus its share in the total traffic is experiencing a continuous increase, as can be seen in Figure 9, from 19.8\% in 2008 to $22.5 \%$ in 2013 .

\section{FIGURE 9}

Total truck traffic diminished during the period in question, most likely due to the 2008-9 economic crisis and the consequent fall in trade and economic activity. According to the Permanent Survey of Freight Transport by Road (Ministerio de Fomento, 2008 and 2013), interprovincial traffic fell by 24\% in Spain, between 2008 and 2013. Figure 10 shows road traffic between the key inland regions (NUTS 2) and the three container port provinces. It can be seen that road traffic (number of heavy vehicles) between Aragón (location of Plaza and TMZ) and Cataluña (Barcelona) is more intense than between Aragón and the ports of Valencia and Bilbao, although it has fallen by about $12 \%$ over the seven-year period. As this decline has not been mirrored by a similar increase in traffic in the other ports, this could be the result of Barcelona shifting to rail. Interestingly, road traffic from Madrid to all port regions has declined. This could be due to modal shift, but as it began during the financial crisis and has not picked up since, it could be a continued reaction to a loss of demand.

\section{FIGURE 10}

A more detailed understanding of these flows, and in particular their evolution over time, is shown in Figure 11 by mapping the road traffic on the main routes connecting the logistic platforms and the ports in 2008 and 2013. It can be seen that the Zaragoza-Valencia route increased its relative weight whereas Madrid-Valencia has reduced its share. Nevertheless, the number of heavy vehicles connecting Zaragoza with Valencia much lower than between Zaragoza and Bilbao or Barcelona. Nevertheless, the reduction of truck traffic on the Madrid- 
Valencia route does not necessarily imply a reduction of the hinterland of the port of Valencia; on the contrary, it has expanded.

FIGURE 11

\section{Terminals and logistics platforms}

Figure 12 shows the evolution of container traffic at the key inland terminals at Madrid and Zaragoza. The figure shows that Plaza has remained steady at a low level while Coslada Madrid and TMZ have climbed very rapidly in the space of one year.

\section{FIGURE 12}

As discussed in Monios (2011), these key terminals have been used as tools of competition by the respective ports. Coslada was developed jointly by the national port body Puertos del Estado and the four major container ports, operated on a concession by a newly established company owned by Noatum (a port terminal operator at Bilbao, Valencia, Málaga \& Las Palmas) and national rail operator RENFE. For the greatest part of its existence, its port traffic has perhaps unsurprisingly been coming from the port of Valencia. TMZ, meanwhile, was operated by a company jointly owned by its co-located logistics platform and the port of Barcelona, hence its major traffic source was Barcelona. PLAZA is a logistics platform developed by the region of Aragón. On the edge of the site a large intermodal terminal is located, developed by national infrastructure owner ADIF and operated by a consortium led by Noatum and including some shareholding from the ports of Bilbao and Barcelona. Therefore, both Coslada and the PLAZA terminal are operated by consortia owned by a major port terminal operator at Valencia and Bilbao. It is however Barcelona that has had the recent significant rail traffic growth. Another interesting change from a few years ago is that the terminal of Azuqueca de Henares, northeast of Madrid, has not managed to maintain its traffic with the port of Barcelona.

Data on the shares of each inland container terminal reveals that each of them is dominated by a single port. At the Madrid Coslada terminal in 2014, Valencia contributed $89 \%$ of a total of 125,000 TEUs, with fewer than a thousand containers from the other two ports. This is a slight change from 2008, when Valencia contributed $82 \%$ of 60,000 TEU, but the difference was that in 2008 the other ports contributed a few thousand containers each. At TMZ, 92\% of their 
current container traffic of over 250,000 TEU comes from the port of Barcelona and the remainder from Bilbao. In the case of Plaza, a container traffic of around 60,000 TEU is all with the port of Bilbao (although it has several trains for other destinations carrying non-unitised cargo).

Increasing interest has been shown to the possibility of using logistics platforms to consolidate traffic, but little empirical data is available due to commercial sensitivity. What does seem apparent is little evidence of such platforms being used to support the growth of rail, as they cannot overcome traditional challenges such as the need to share information and align shipments between several different shippers. Therefore, the co-location of a large intermodal terminal with the logistics platform at Plaza has not led to increased use of rail and only about $2 \%$ of traffic from the site uses the rail terminal.

\section{Discussion and conclusion}

The research question of this paper was to what extent the development of inland terminals and container rail shuttles has influenced the ability of Spanish ports to compete for distant hinterlands. While commercial data availability limits the extent to which this question can be answered in its entirety, a number of conclusions have been drawn. In the Spanish case, it is clear that the development of rail services has not been necessary to expand contestable port hinterlands, as Valencia has grown its share of both Madrid and Zaragoza while experiencing a declining share in overall rail volumes. While Valencia has increased its use of rail to Madrid, doubling its container throughput to the Coslada terminal in six years, this has merely maintained its share of rail on that route. Bilbao has grown its share of rail while losing ground in both key inland markets. Barcelona showed a large increase in rail, in particular with a large burst at the TMZ rail terminal, yet only managing to maintain its share of Madrid and Zaragoza regional traffic.

Thus, Zaragoza continues to favor its nearest port of Barcelona, while Madrid's closest port of Valencia also maintains its dominance in that region. These findings support the hypothesis of Garcia-Alonso and Sanchez-Soriano (2009) that hinterland distance is still an important variable for inland freight transport, meaning that firms, when selecting their location, take into account the location of the ports offering the services they need, whereas firms already established tend to choose the services offered by the nearest port.

Garcia-Alonso et al (2016) found that between 2000 and 2010 Valencia grew the size of its hinterland and also decreased its spatial concentration of traffic (particularly with regard to exports). This decrease in concentration would reduce the ability to consolidate traffic on rail 
shuttles, which could explain the only small success in developing rail traffic to the port of Valencia. Interestingly, the port of Barcelona also experienced a (smaller) decrease in concentration, but it was still able to develop rail flows. However, these findings only account for 2000-2010. The more recent changes in rail activity observed in this paper do not correlate directly with the previous analysis. The conclusion is therefore that the port of Valencia should seek to grow its volumes in less concentrated areas, around rail terminals. On the other hand, as shown in the Plaza case (a terminal co-located with a logistics platform, linked directly to the port of Valencia and part-operated by the container terminal operator), the growth in logistics platforms does not always translate into increased use of rail. This is likely due to the fact that distance remains competitive to road haulage, therefore successful rail shuttles cannot rely on natural distance advantages of rail and must compete on cost, flexibility, reliability and so on. The intermodal literature demonstrates the difficulty of such achievements over relatively short distances.

The final conclusion therefore relates to the port choice literature. As the Spanish case demonstrates, rail transport is not a necessary condition to grow hinterlands. The conclusion could thus be drawn that, in countries with the geographical morphology such as that of Spain, securing good quality rail transport is a lower priority for ports compared to other port choice factors, over which ports generally have more control. This said, it needs to be kept in mind that port choice is a private decision while the development of rail infrastructure is a public one. More often than not, the two diverge. The Spanish case may be generalized to cases of ports serving hinterlands at short/medium distance, in which investments in inland terminals tend to be speculative and based on public support. This finding may be different in other cases where land distances are greater than in Spain; in such cases rail would have a natural advantage. Indeed, there always remain contextual factors in each case, such as the ports each shipping line calls, or whether inland haulage is controlled by the shipper or the carrier. More research is needed to test the quantitative findings of this paper with qualitative interview data that may allow greater focus on the changing port choice factors in Spanish ports in recent years. 


\section{References}

Agencia Tributaria. 2016. Datos Estadísticos de Comercio Exterior. Accessed February 24. http://www.agenciatributaria.es/AEAT.internet/Inicio_es_ES/La_Agencia_Tributaria/Memorias_y_ estadisticas_tributarias/Estadisticas/Comercio_exterior/Comercio_exterior.shtml.

Berg, Roy Van den, and Peter W. De Langen. 2011. Hinterland Strategies of Port Authorities: A Case Study of the Port of Barcelona. Research in Transportation Economics 33 (1): 6-14.

Bergqvist, Richard, G. Falkemark, and Johan Woxenius. 2010. Establishing Intermodal Terminals. World Review of Intermodal Transportation Research 3 (3): 285-302.

Bichou, Khalid, and R Gray. 2004. A Logistics and Supply Chain Management Approach to Port Performance Measurement. Maritime Policy and Management 31 (1): 47-67.

Cámara de Comercio de España. 2016. Directorio de Empresas Exportadoras E Importadoras. España. Accessed February 24. http://directorio.camaras.org/.

Ente Público Puertos del Estado. 2016. Anuario Estadístico. Accessed February 24. http://www.puertos.es/es-es/estadisticas/RestoEstadísticas/Paginas/Resto-estadisticas.aspx.

Ferrari, Claudio, Francesco Parola, and E Gattorna. 2011. Measuring the Quality of Port Hinterland Accessibility: The Ligurian Case. Transport Policy 18 (2): 382-91.

Garcia-Alonso, Lorena, Ana Martinez-Pardo, and José Ángel Vallejo-Pinto. 2016. Analysis of the Spatial Development of the Hinterland of Ports: A Case Study. International Journal of Shipping and Transport Logistics 8 (2): 111-28.

Garcia-Alonso, Lorena, and Joaquin Sanchez-Soriano. 2009. Port Selection from a Hinterland Perspective. Maritime Economics and Logistics 11 (3): 260-69. doi:10.1057/mel.2009.9.

Garcia-Alonso, Lorena, and Joaquin Sanchez-Soriano. 2010. Analysis of the Evolution of the Inland Traffic Distribution and Provincial Hinterland Share of the Spanish Port System. Transport Reviews 30 (3). Routledge: 275-97. doi:10.1080/01441640902985983.

Graham, M. G. 1998. Stability and Competition in Intermodal Container Shipping: Finding a Balance. Maritime Policy and Management 25 (2): 129-47.

Guerrero, David. 2014. Deep-Sea Hinterlands: Some Empirical Evidence of the Spatial Impact of Containerization. Journal of Transport Geography 35: 84-94.

Klink, Van; H.A., and Geerke C. van den Berg. 1998. Gateways and Intermodalism. Journal of Transport Geography 6 (1): 1-9.

Martínez-Pardo, Ana, and Lorena Garcia-Alonso. 2014. Analysis of the Inland Port Regionalization Process in Spain. Procedia - Social and Behavioral Sciences 162: 228-36. doi:http://dx.doi.org/10.1016/j.sbspro.2014.12.203.

McCalla, Robert J. 1999. Global Change, Local Pain: Intermodal Seaport Terminals and Their Service Areas. Journal of Transport Geography 7 (4): 247-54.

Ministerio de Fomento. 2016a. Anuario Estadístico. Accessed February 24. http://www.fomento.gob.es/MFOM/LANG_CASTELLANO/ATENCION_CIUDADANO/INFORMACION _ESTADISTICA/Transporte/. 
Ministerio de Fomento. 2016b. Mapa de Carreteras. Madrid. Accessed February 24. http://www.fomento.gob.es/MFOM/LANG_CASTELLANO/DIRECCIONES_GENERALES/CARRETERAS/ TRAFICO_VELOCIDADES/MAPAS/SERIE_HISTORICA/2013/.

Monios, Jason. 2011. The Role of Inland Terminal Development in the Hinterland Access Strategies of Spanish Ports. Research in Transportation Economics 33 (1): 59-66.

Monios, Jason. 2015. Identifying Governance Relationships Between Intermodal Terminals and Logistics Platforms. Transport Reviews 35 (6): 767-91.

Monios, Jason, and Bruce Lambert. 2013. Intermodal Freight Corridor Development in the United States. In Dry Ports: A Global Perspective, edited by R. Bergqvist, G. Wilmsmeier, and K. Cullinane, 197218. London: Ashgate Publishing Limited.

Monios, Jason, and Y Wang. 2013. Spatial and Institutional Characteristics of Inland Port Development in China. GeoJournal 78 (5): 897-913.

Monios, Jason, and Gordon Wilmsmeier. 2012. Giving a Direction to Port Regionalisation. Transportation Research Part A: Policy and Practice 46 (10): 1551-61.

Monios, Jason, and Gordon Wilmsmeier. 2013. The Role of Intermodal Transport in Port Regionalisation. Transport Policy 30: 161-72.

Nazemzadeh, M, and T Vanelslander. 2015. The Container Transport System. Maritime Economics and Logistics 17 (2). Palgrave Macmillan: 221-45. http://dx.doi.org/10.1057/mel.2015.1.

Notteboom, Theo E. 2008. Bundling of Freight Flows and Hinterland Network Developments. In The Future of Intermodal Freight Transport, Operations, Technology, Design and Implementation, edited by P. Konings, R., Priemus, H., Nijkamp, 66-88. Cheltenham, UK: Edward Elgar Publishing, Inc.

Notteboom, Theo E. 2010. Concentration and the Formation of Multi-Port Gateway Regions in the European Container Port System: An Update. Journal of Transport Geography 18 (4): 567-83.

Notteboom, Theo E, and Jean-Paul Rodrigue. 2005. Port Regionalization: Toward a New Phase in Port Development. Maritime Policy and Management 32 (3): 297-313.

Notteboom, Theo E, and W Winkelmans. 2001. Structural Changes in Logistics: How Will Port Authorities Face the Challenge? Maritime Policy and Management 28 (1): 71-89.

Olivier, D, and Brian Slack. 2006. Rethinking the Port. Environment and Planning A 38 (8): 1409-27.

Parola, Francesco, and A Sciomachen. 2009. Modal Split Evaluation of a Maritime Container Terminal. Maritime Economics and Logistics 11 (1): 77-97.

Rodrigue, Jean-Paul, Jean Debrie, Antoine Fremont, and Elisabeth Gouvernal. 2010. Functions and Actors of Inland Ports: European and North American Dynamics. Journal of Transport Geography 18 (4): 519-29.

Song, Dong-Wook, and Ki-Tae Yeo. 2004. A Competitive Analysis of Chinese Container Ports Using the Analytic Hierarchy Process. Maritime Economics and Logistics 6 (1): 34-52.

UNCTAD, 2013. The way to the ocean: Transit corridors servicing the trade of landlocked developing countries. Geneva: United Nations. 
Veldman, Simme, Lorena Garcia-Alonso, and José Ángel Vallejo-Pinto. 2011. Determinants of Container Port Choice in Spain. Maritime Policy and Management 38 (5). Routledge: 509-22. doi:10.1080/03088839.2011.597450.

Voorde, Eddy Van de, and Thierry Vanelslander. 2009. Market Power and Vertical and Horizontal Integration in the Maritime Shipping and Port Industry. 2009-2. Discussion Paper.

Wilmsmeier, Gordon, Jason Monios, and Bruce Lambert. 2011. The Directional Development of Intermodal Freight Corridors in Relation to Inland Terminals. Journal of Transport Geography 19 (6): 1379-86. 


\section{FIGURES}

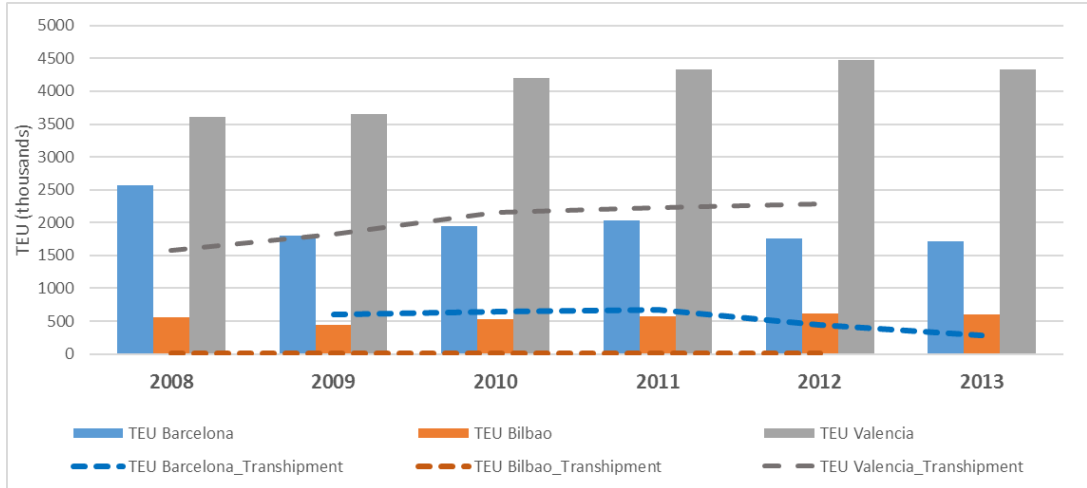

Figure 1 - Evolution of TEU and TEU Transhipment

Source: Anuario Estadístico, Puertos del Estado (2008-2013).

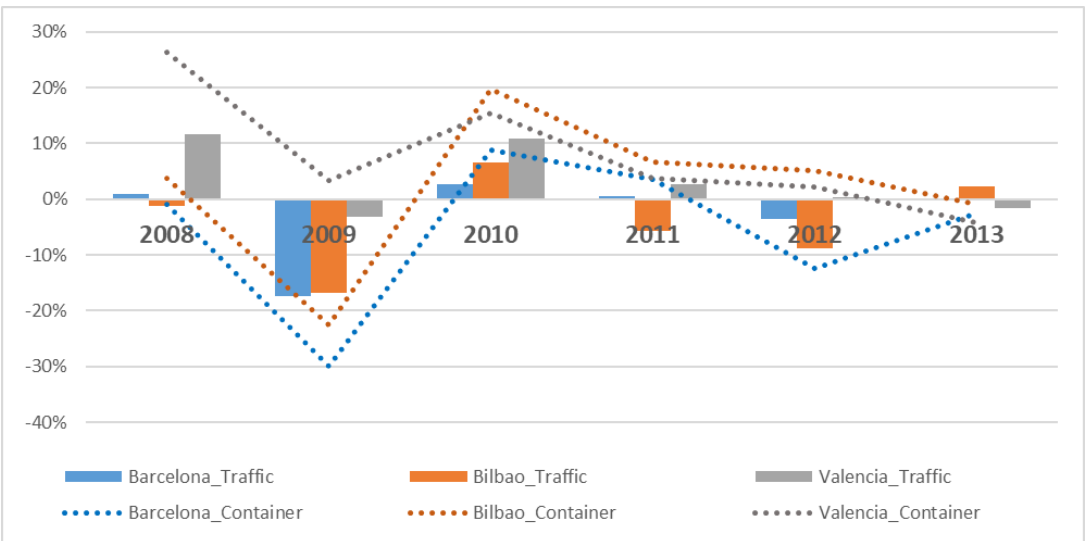

Figure 2 - Rate of growth of freight traffic and container movement

Source: Anuario Estadístico, Puertos del Estado (2008-2013). 


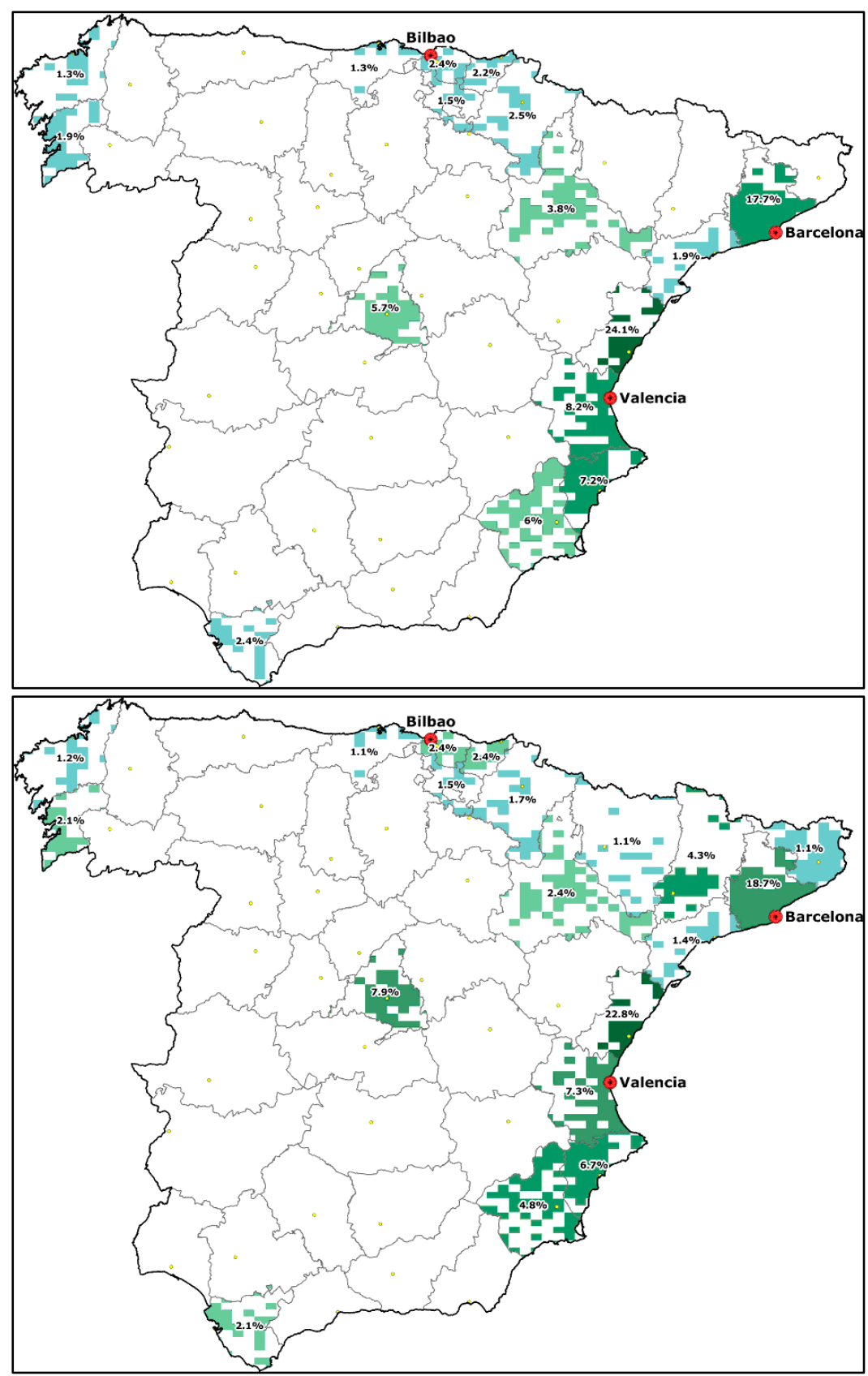

Figure 3 - Distribution of Spanish port traffic in 2008 and 2013

Source: Agencia Tributaria and Cámara de Comercio de España. 

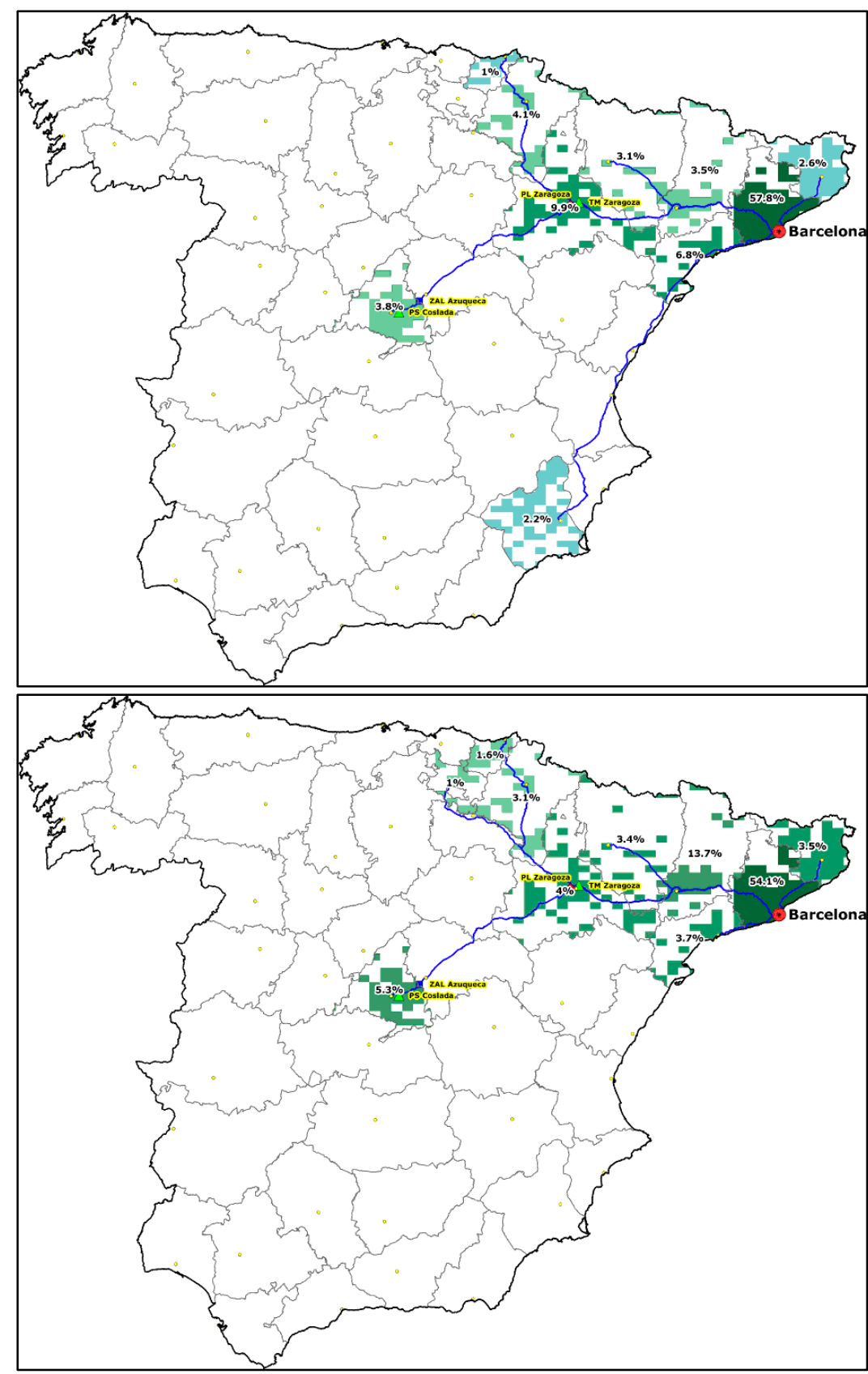

Figure 4 - Mapping of port flows Barcelona 2008, 2013

Source: Agencia Tributaria, Cámara de Comercio de España, Ministerio de Fomento (2008, 2013). 


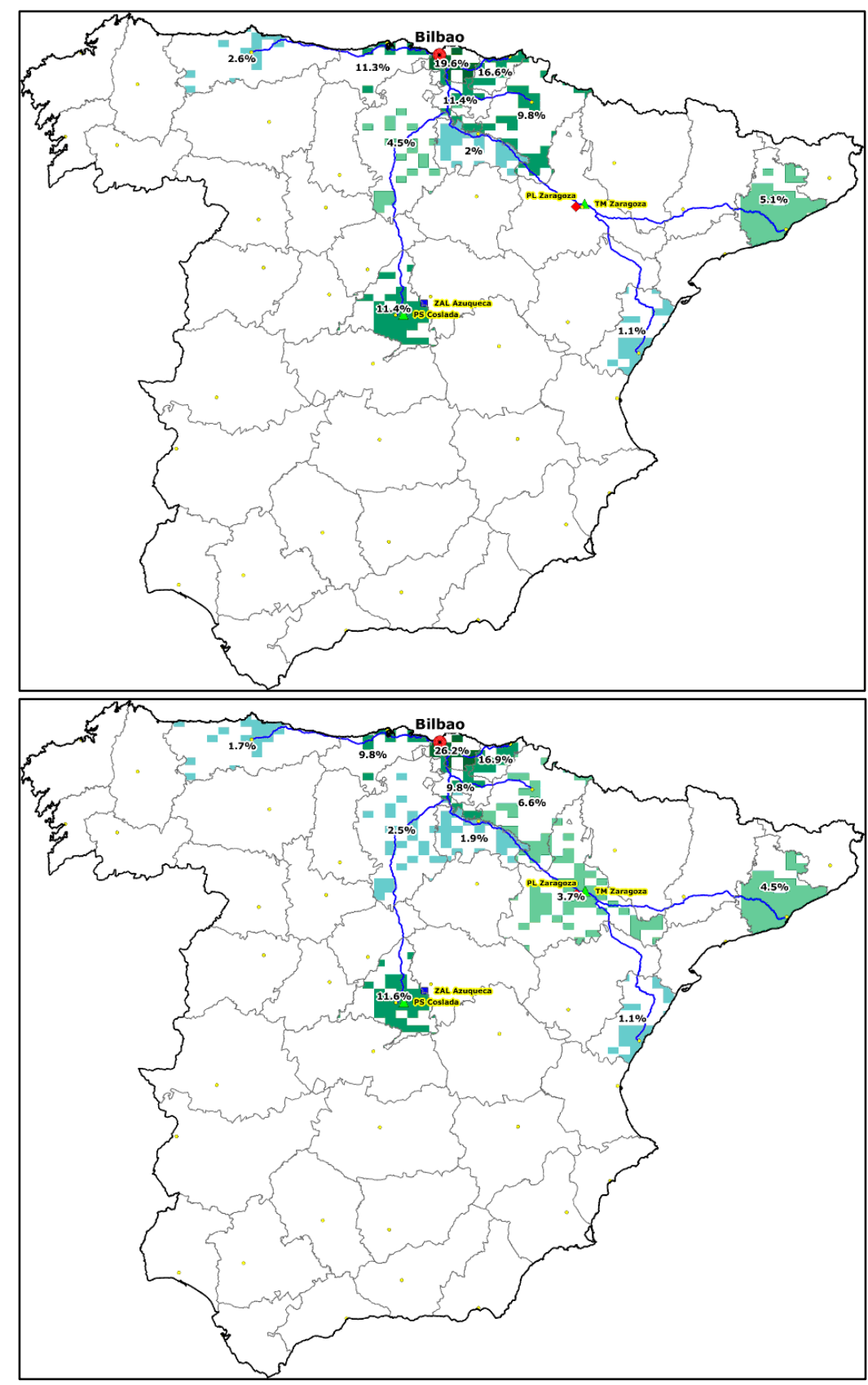

Figure 5 - Mapping of port flows Bilbao 2008, 2013

Source: Agencia Tributaria, Cámara de Comercio de España, Ministerio de Fomento (2008, 2013). 

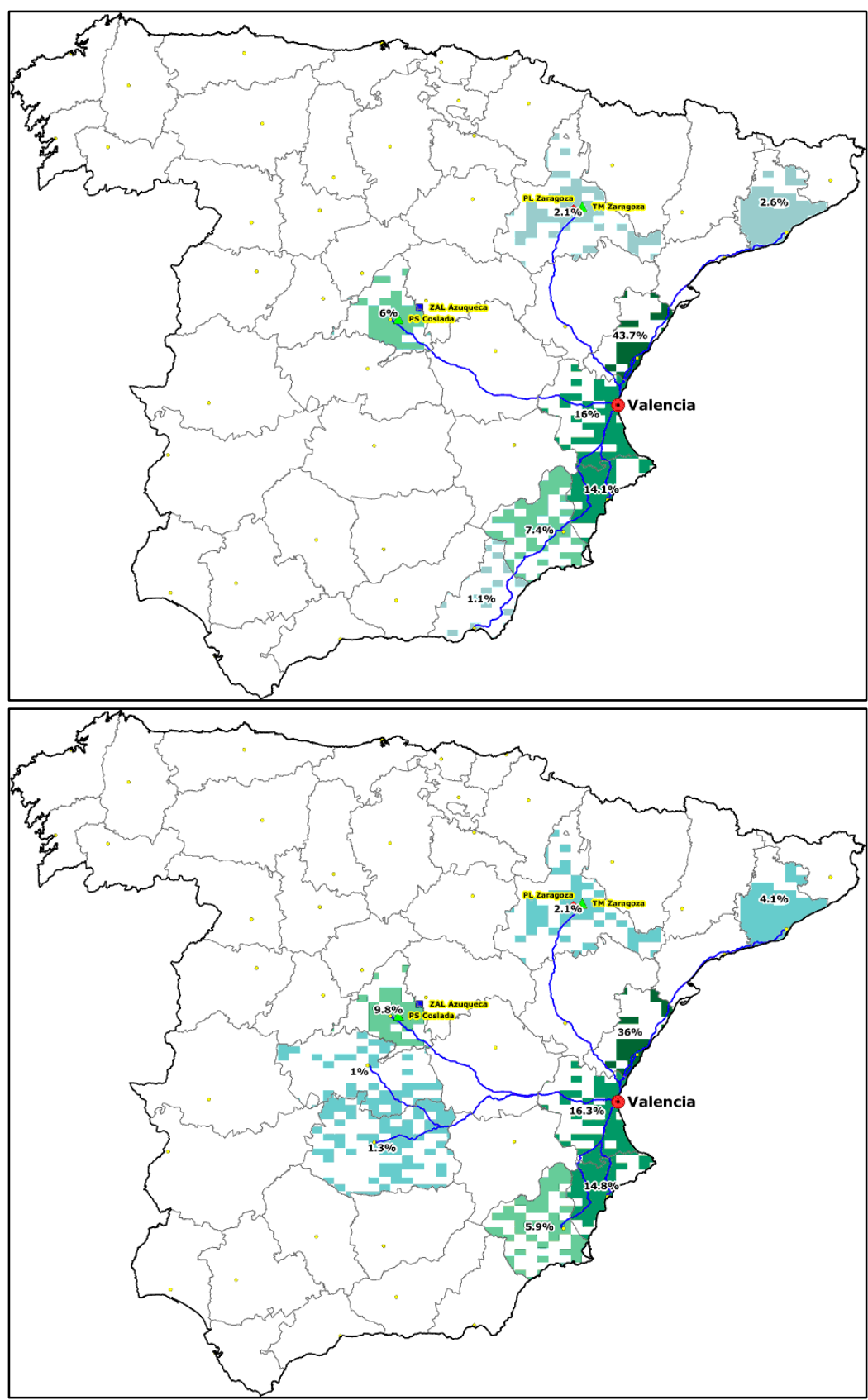

Figure 6 - Mapping of port flows Valencia 2008, 2013

Source: Agencia Tributaria, Cámara de Comercio de España, Ministerio de Fomento (2008, 2013). 

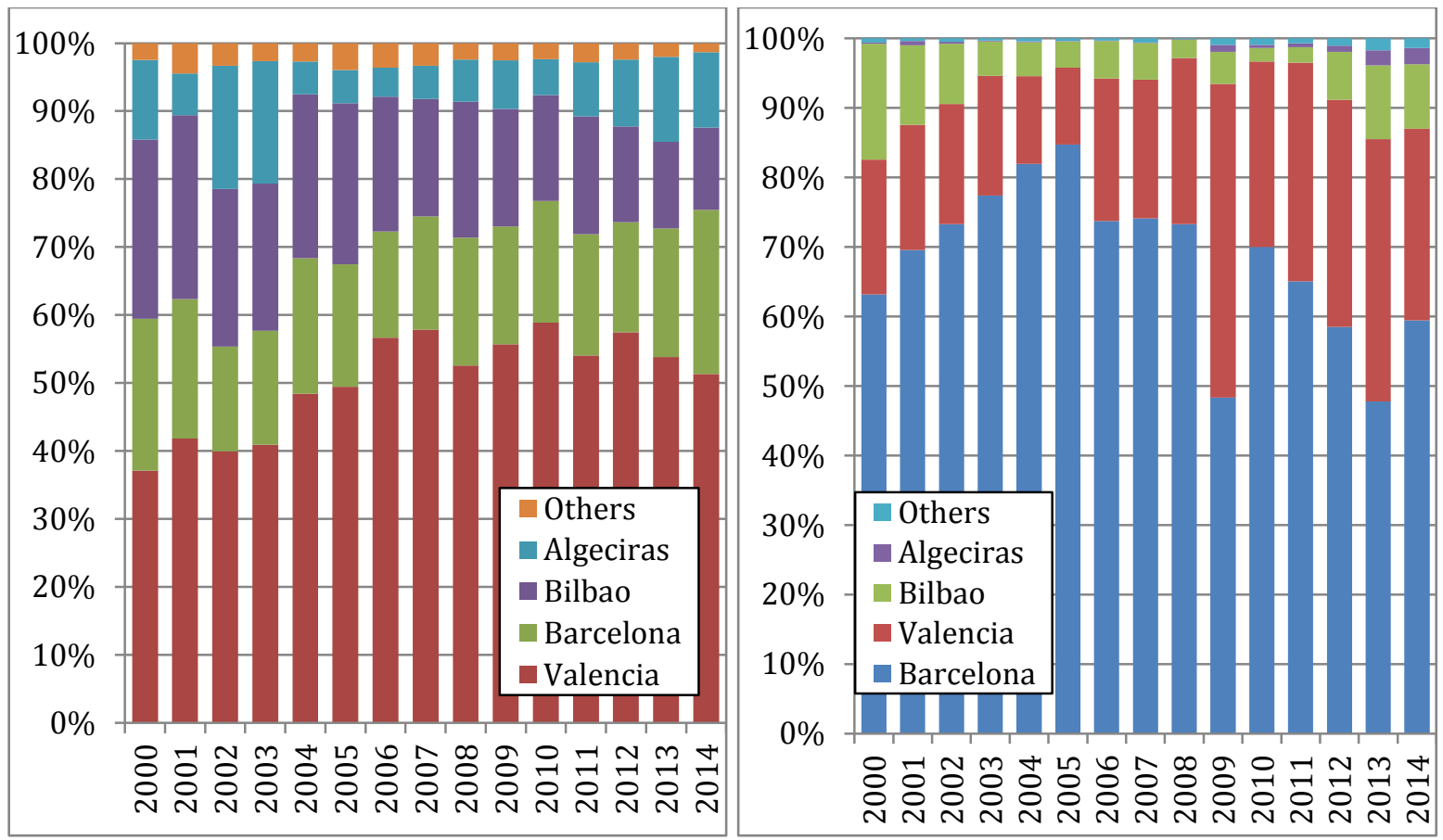

Figure 7 - Share of provincial traffic per port for Madrid (left) and Zaragoza (right)

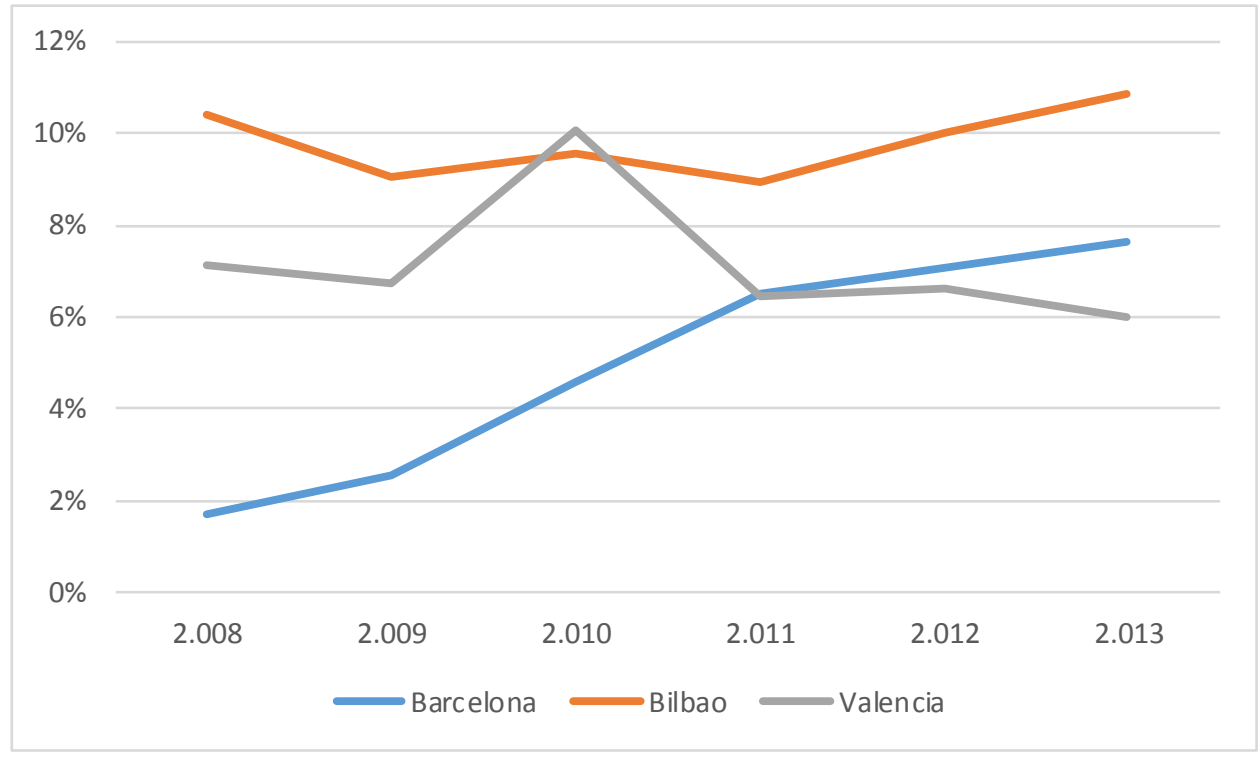

Figure 8 - Modal share of rail traffic at each port 2008-2013

Source: Anuario Estadístico, Puertos del Estado (2008-2013) 


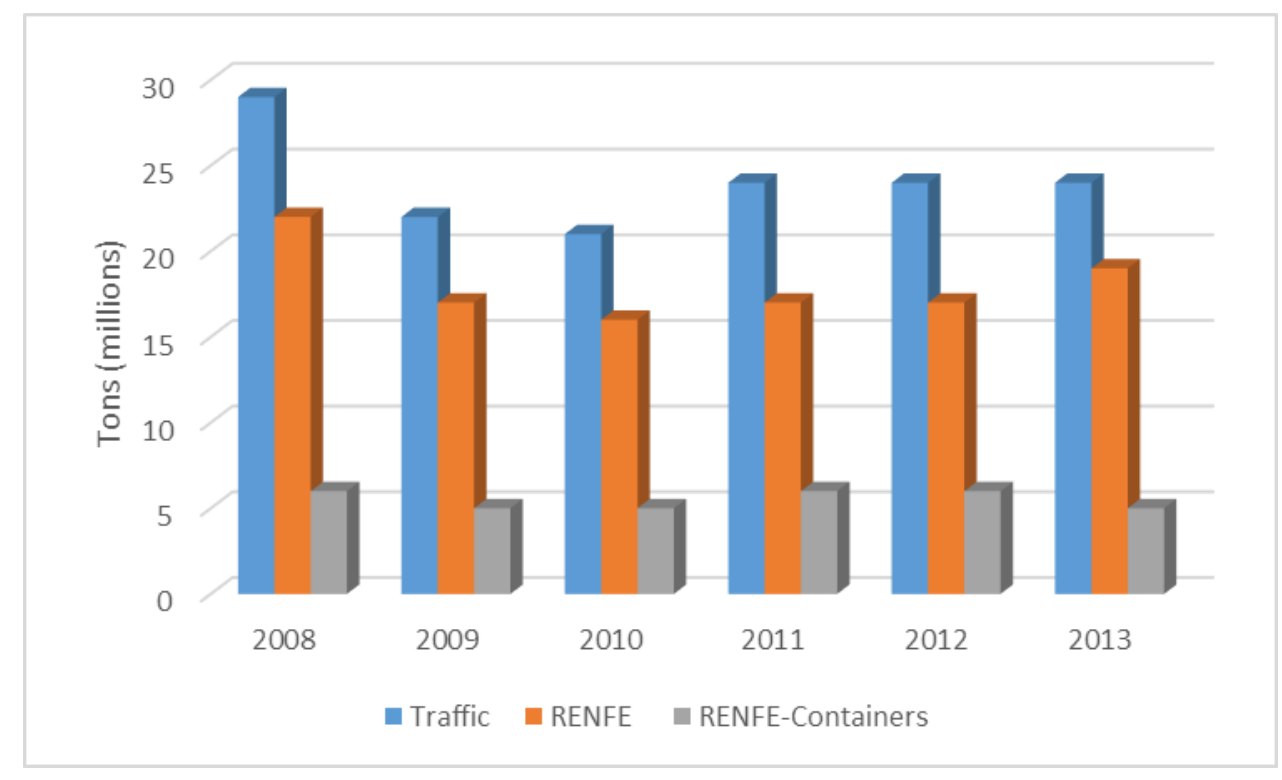

Figure 9 - Railway traffic evolution in Spain 2008-2013

Source: Anuario estadístico, Ministerio de Fomento (2014)

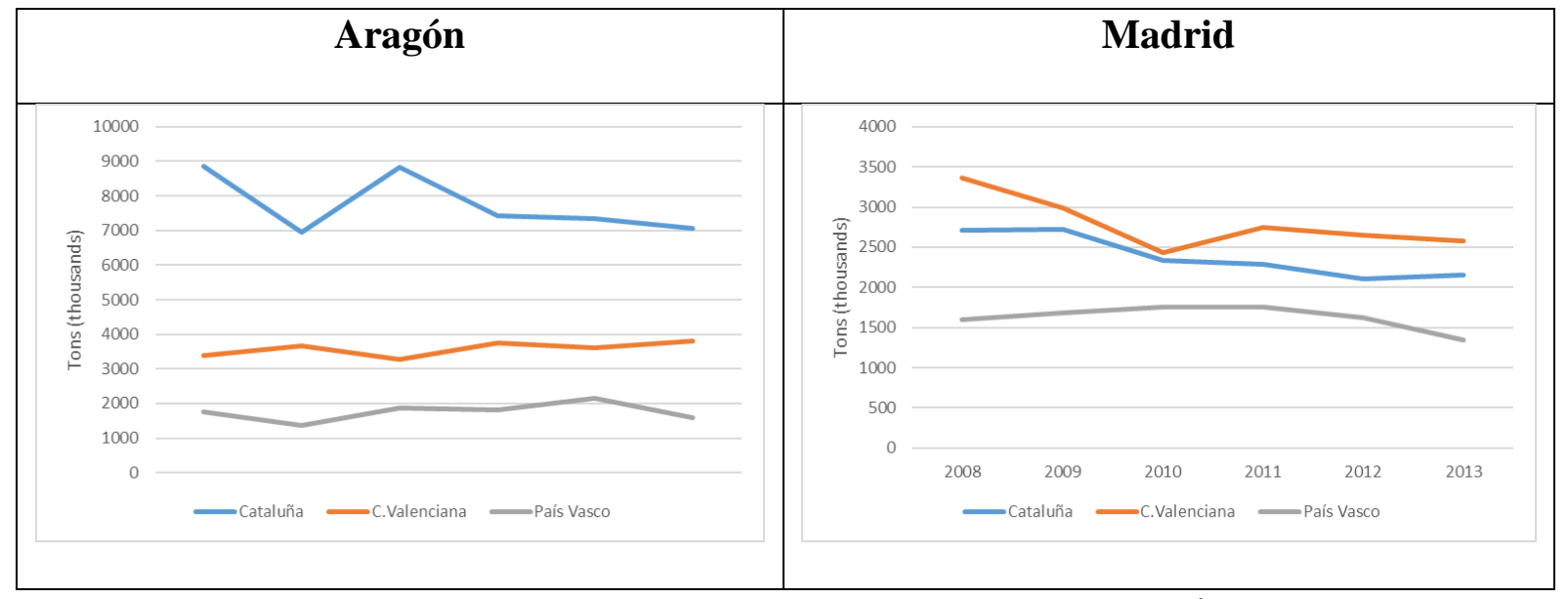

Figure 10 - Road traffic between the two inland provinces of Aragón/Madrid and the three ports

Source: Permanent Survey of Freight Transport by Road (Ministerio de Fomento, 2008, 2013) 


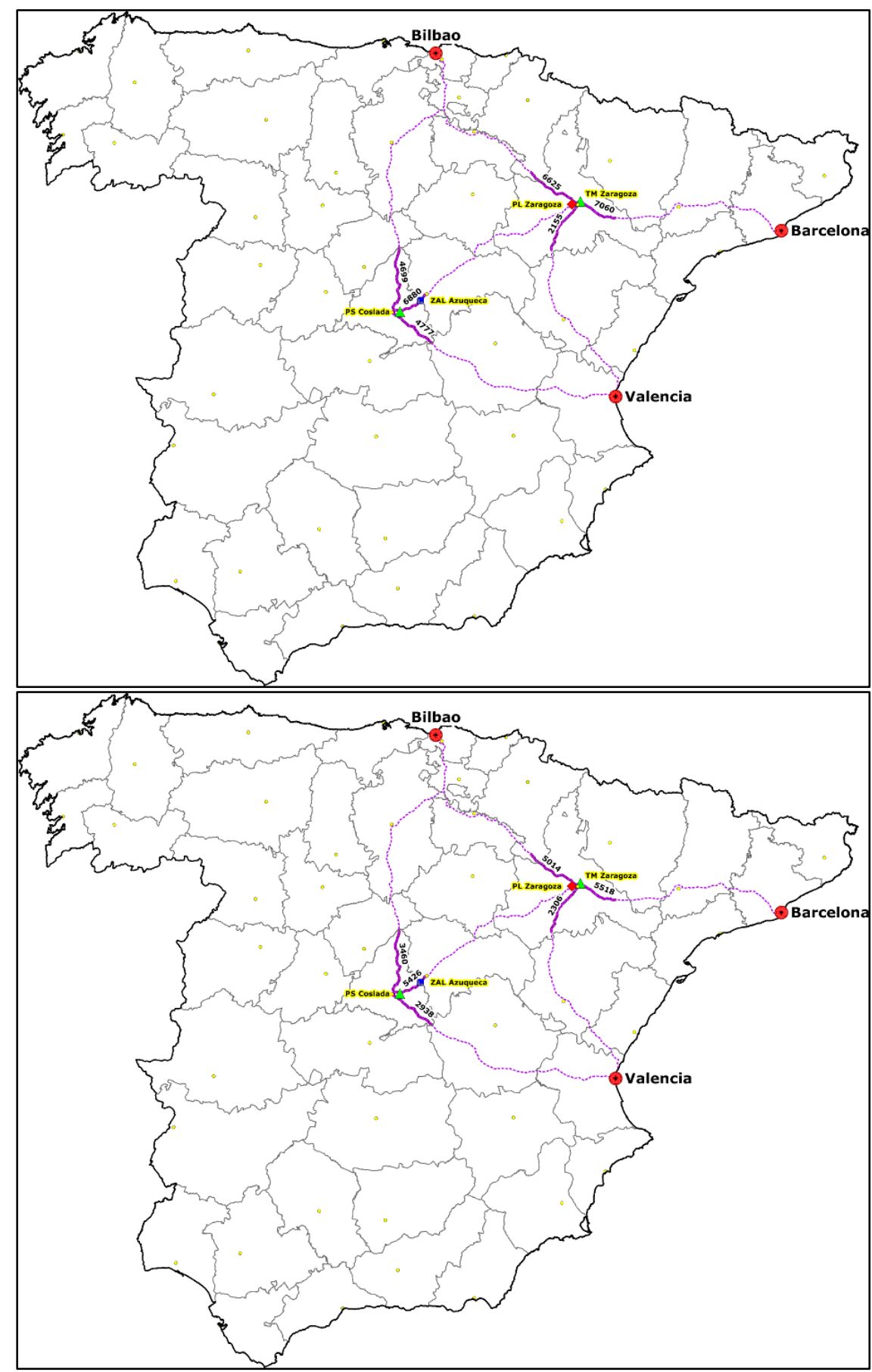

Figure 11 - Heavy trucks from/to Zaragoza-Madrid and the main ports 2008, 2013

Source: Traffic map 2013. Ministerio de Fomento. 


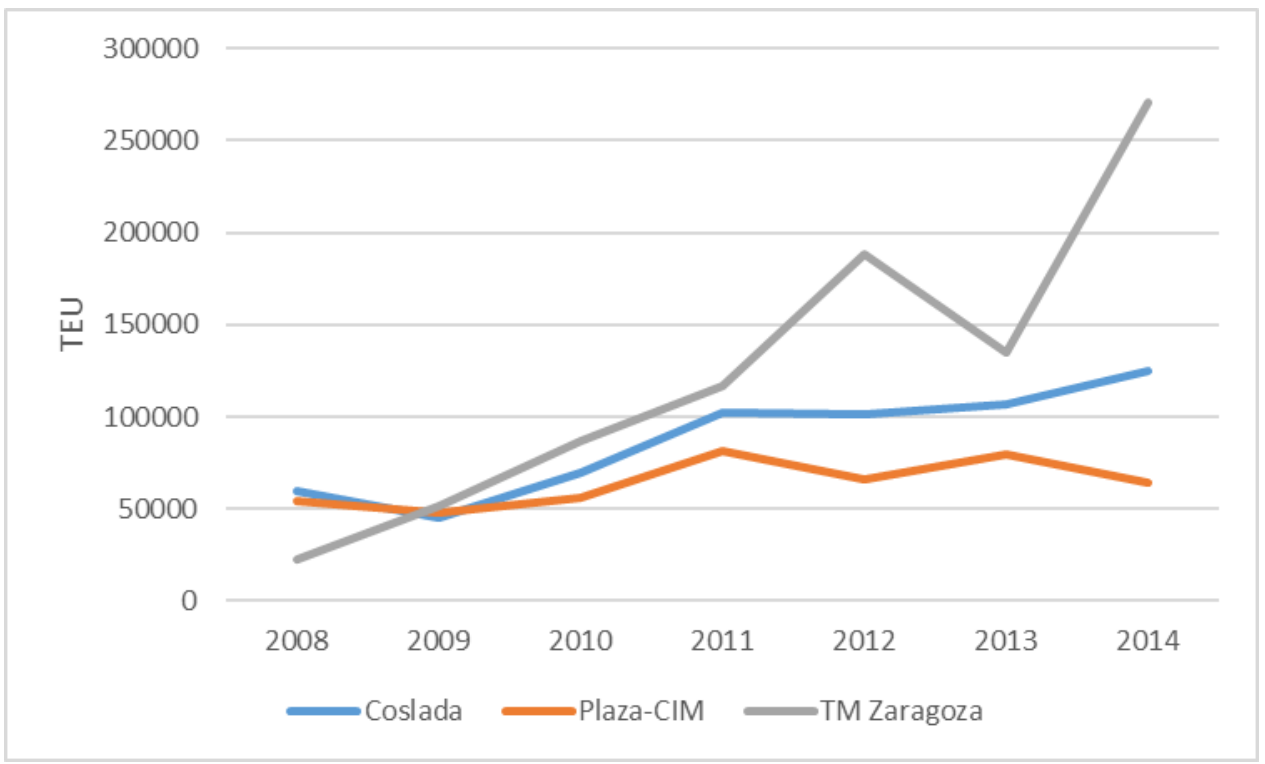

Figure 12 - Container traffic evolution at major inland terminals

Source: individual terminals 